\title{
RANCANGAN MEJA ANTI NGANTUK PADA SISWA SEKOLAH DASAR MENGGUNAKAN ANDROID DAN BLUETOOTH BERBASISKAN ARDUINO UNO
}

\author{
Deny Nusyirwan"), Abdilah Husaini' ${ }^{2)}$ \\ 1) Jurusan Teknik Elektro, Fakultas Teknik, Universitas Maritim Raja Ali Haji (UMRAH) \\ 2) Jurusan Teknik Elektro, Fakultas Teknik, Universitas Maritim Raja Ali Haji (UMRAH) \\ Email: denynusyirwan@umrah.ac.id, abdillahhusaini1906@gmail.com
}

\begin{abstract}
ABSTRAK
Aktifitas siswa dalam bersekolah memerlukan kondisi kesehatan yang baik dan juga istirahat yang cukup untuk dapat bangun pagi. Banyak kegiatan yang bisa dilakukan para siswa di sekolah, mulai dari aktivitas belajar, bermain, dan berolahraga. Oleh karena itu, tidak jarang siswa akan mulai mengantuk pada jam pelajaran setelah tengah hari. Keadaan ini tentu akan mengurangi konsentrasi siswa dalam menerima pelajaran dan dapat mengganggu rekan didalam kelas. Adapun cara yang diakukan hingga saat ini adalah guru mendatangi siswa yang mengantuk tersebut dan meminta keluar kelas untuk membasuh mukanya dengan air sehingga rasa kantuk hilang. Hal ini tentu akan merepotkan guru dan mengurangi konsentrasi belajar siswa lainnya. Solusi berupa inovasi berbasiskan teknologi yang diusulkan adalah meja anti ngantuk, sebuah purwarupa berbasiskan mikrokontroler arduino uno yang di integrasikan dengan fungsi bluetooth dan buzzer. Apabila guru melihat siswa yang sudah mulai mengantuk, maka guru dapat menekan sebuah tombol yang sudah ditentukan pada telepon pintar miliknya, selanjutnya melalui akses bluetooth maka Arduino akan menghidupkan buzzer yang ditempatkan pada meja siswa, sehingga siswa akan tersadar dan mulai konsentrasi kembali mendengarkan. Proses penelitian dimulai dengan pendekatan Double Diamond yang diperkenalkan oleh British Design Council, yaitu proses perancangan menggunakan pendekatan secara sosial melalui aktivitas bersama calon pengguna inovasi yang di integrasikan dengan design thinking untuk menghasilkan inovasi berbasis teknologi yang bermanfaat bagi calon pengguna tersebut.
\end{abstract}

Kata kunci: Aktifitas siswa, mengantuk, teknologi, arduino

\begin{abstract}
Student activities in school require good health conditions and adequate rest to get up early. Many activities can be done by students at school, starting from learning, playing, and exercising. Therefore, it is not uncommon for students to get sleepy during class after midday. This situation will certainly reduce the concentration of students in receiving lessons and can interfere with colleagues in the classroom. The way to do this now is that the teacher comes to the sleepy student and asks the class to wash their face with water so that sleepiness disappears. This will certainly inconvenience the teacher and reduce the learning concentration of other students. The solution in the form of technology-based innovation proposed is a desk for anti-drowsiness, a prototype based on the Arduino Uno microcontroller that is integrated with Bluetooth and buzzer functions. If the teacher sees students who have started to get sleepy, then the teacher can press a button that has been determined on his smartphone, then through Bluetooth access the Arduino will turn on the buzzer placed on the student desk, so the student will wake up and start concentrating again listening. The research process began with the Double Diamond approach introduced by the British Design Council, namely the design process using a social approach through activities with prospective users of innovation that are integrated with design thinking to produce technology-based innovations that are useful for prospective users.
\end{abstract}

Keywords : Student activities, sleepiness, technology, Arduino 


\section{PENDAHULUAN}

Siswa yang mengalami kelelahan setelah sibuk beraktifitas ataupun keadaan cuaca akan dapat menimbulkan kantuk pada siswa. Siswa yang mengantuk didalam kelas ketika pelajaran sedang berlangsung akan mengalami kerugian karena tidak dapat menerima pelajaran yang disampaikan oleh guru yang sedang mengajar, Selain permasalahan tersebut, konsentrasi rekan didalam kelas akan terganggu karena guru yang datang menghampiri siswa yang mengantuk tersebut. Apabila peristiwa ini berlangsung pada beberapa siswa didalam kelas tersebut tentu akan mengganggu aktivitas pelajaran didalam kelas tersebut. Oleh sebab itu, di usulkan sebuah inovasi berbasiskan teknologi yang dinamakan meja anti ngantuk. Inovasi ini berbasiskan mikrokontroler arduino dan telepon pintar dengan sistem operasi android yang terhubung secara bluetooth untuk mengakifkan buzzer yang ditempatkan pada masing-masing meja siswa di kelas. penelitian dimulai dengan pendekatan Double Diamond yang diperkenalkan oleh British Design Council, yaitu memulai proses perancangan dengan social research dan design thinking untuk dapat menghasilkan inovasi berbasis teknologi yang bermanfaat bagi calon pengguna. Setelah mendapatkan solusi utama dari permasalahan utama calon pengguna, maka akan dilanjutkan dengan pembuatan purwarupa sederhana yang akan dipergunakan untuk uji fungsi dan manfaat bersama calon pengguna.

Beberapa penelitian terdahulu sudah dilakukan untuk menghindari dan menyadarkan manusia dari rasa kantuk. Penelitian dengan cara mengambil citra mata melalui kamera digital dengan melalui proses komputerisasi dapat diketahui seseorang tersebut sedang mengantuk sudah dilakukan, inovasi ini ditujukan pada pengendera kendaraan bermotor [1]. Selain itu mendeteksi pengemudi sedang mengantuk, dengan menggunakan foto transistor, dengan perubahan percepatan darah yang mengalir akan mengurangi intensitas dari LED sehingga akan terdeteksi oleh sensor. Sistem ini juga di integrasikan dengan fungsi getaran pada helm apabila pengemudi sudah terdeteksi mengantuk [2]. Selain itu, sistem mendeteksi kantuk dengan menggunakan pulse sensor yang di integrasikan dengan mikrokontroler juga dilakukan, dimana pada jumlah denyut tertentu maka mikrokontroler akan memerintahkan buzzer berfungsi, sistem ini juga dilengkapi dengan fungsi getar [3]. inovasi berbasiskan teknologi mikrokonroller Arduino yang di integrasikan dengan sensor detak jantung untuk medapatkan nilai detak jantung per menit. Selanjuntya mempergunakan modul GSM yang akan mengirimkan informasi ke nomor yang terdaftar terkait detak jantung pasien apabila tidak normal. Untuk mengetahui posisi pasien tersebut, maka dipergunakan modul GPS [4].

\section{METODE}

Peranan penting bagi ilmuwan pada abad ke-21 adalah berperan serta dalam mendidik masyarakat tentang metode dan hasil proses ilmiah [5], oleh sebab itu diperlukan proses desain rekayasa untuk mampu menghasilkan inovasi berbasiskan teknologi yang semakin berkembang dan memiliki fungsi yang tepat dan mudah untuk digunakan.

\section{A. Proses Perancangan Rekayasa}

Jika di masa lalu desainer dievaluasi hanya berdasarkan pada keterampilan teknis mereka, di masa depan akan lebih banyak lagi kebutuhan untuk desainer yang bersedia bekerja dengan pendekatan yang lebih sistemik dan strategis dalam skala yang lebih besar [6].

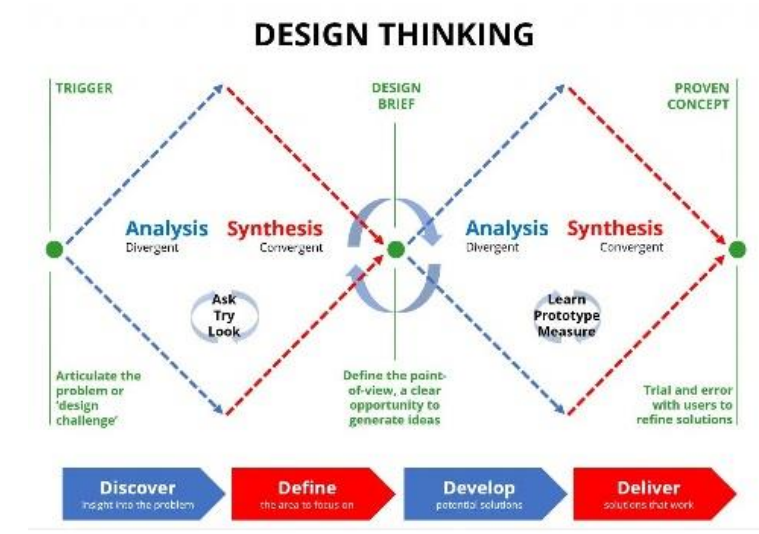

Gambar 1. Tahapan pada Proses Desain Rekayasa [7] 
Proses Desain Rekayasa adalah merupakan sebuah proses didalam mendesain dengan berpusat kepada pengguna. dimulai dengan etnografi hingga menghasilkan sebuah purwarupa yang merupakan sebuah konsep solusi yang sesuai dengan kebutuhan di masyarakat.

Pada tahapan awal dimulai dengan observasi secara luas untuk mendapatkan informasi. Selanjutnya pada tahapan awal adalah menemukan permasalahan-permasalahan setelah melakukan observasi, tahapan kedua adalah proses pengerucutan permasalahan-permasalahan sehingga menemukan sebuah permasalahan utama, tahapan ketiga adalah mengembangkan ide-ide yang merupakan solusi terhadap permasalahan utama dan tahapan terahir adalah menentukan solusi utama. Sila lihat Gambar 1. Setelah menemukan solusi utama maka dilanjutkan ke tahapan pembuatan purwarupa sederhana, pengujian fungsi dan pengalaman terhadap pengguna

\section{B. Etnografi}

Desain dan pemasaran adalah dua bagian penting dalam proses penelitian untuk melakukan pengembangan produk dan menghasilkan inovasi berbasis teknologi. Kedua bidang tersebut dapat saling melengkapi namun memiliki fokus yang berbeda. Peneliti untuk bidang desain sangat ingin tahu apa yang benar-benar dibutuhkan oleh calon pengguna dan bagaimana sebenarnya pengguna akan menggunakan produk yang sedang dipersiapkan. Sedangkan untuk peneliti di bidang pemasaran ingin tahu apa yang akan dibeli pengguna, termasuk mempelajari bagaimana pengguna membuat keputusan pembelian. Oleh sebab itu, dengan tujuan yang berbeda ini akan mengarahkan kedua kelompok tersebut untuk mengembangkan metode penyelidikan yang berbeda pula.

Desainer cenderung menggunakan metode observasi kualitatif yang dengannya mereka dapat mempelajari orang secara mendalam, memahami bagaimana mereka melakukan kegiatan mereka dan faktor lingkungan yang ikut berperan [8]. Metode ini sangat memakan waktu, sehingga didalam penelitian ini hanya memeriksa sejumlah kecil orang.. Adapun metode observasi yang dipergunakan adalah metode observasi peneliti sebagai peserta (observer as participant), yaitu kelompok yang sedang diteliti mengetahui tentang keberadaan peneliti, namun peneliti tidak ikut serta melakukan kegiatan dan aktifitas didalam kelompok yang sedang diteliti. Lokasi penelitian dilakukan di SDN011 Tanjung pinang timur, Kepulauan Riau, lihat Gambar 2.
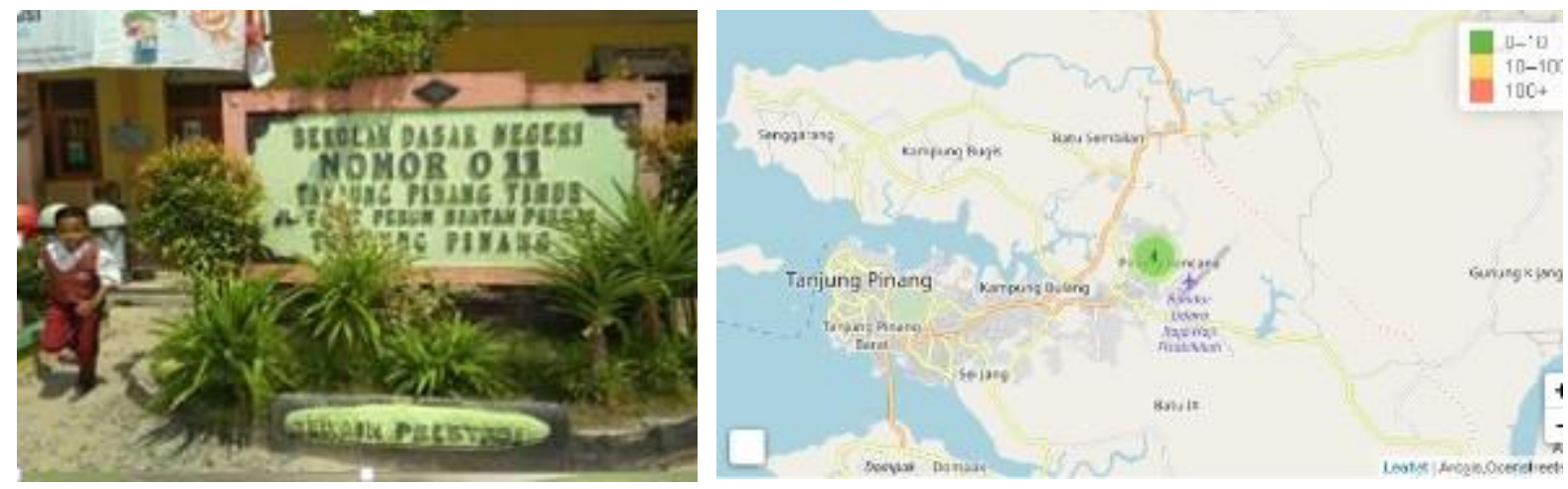

Gambar 2. Lokasi SDN 011 Tanjung pinang timur [9]

Langkah awal dari Proses Desain Rekayasa, yang merupakan aktivitas pegamatan atau observasi secara langsung ke masyarakat di suatu daerah untuk mendapatkan data yang akurat sehingga mampu menghasilkan sebuah solusi yang tepat. Pada Gambar 3 menampilkan keadaaan di SDN 011 Tanjung pinang timur untuk mendapatkan data-data yang di perlukan. 

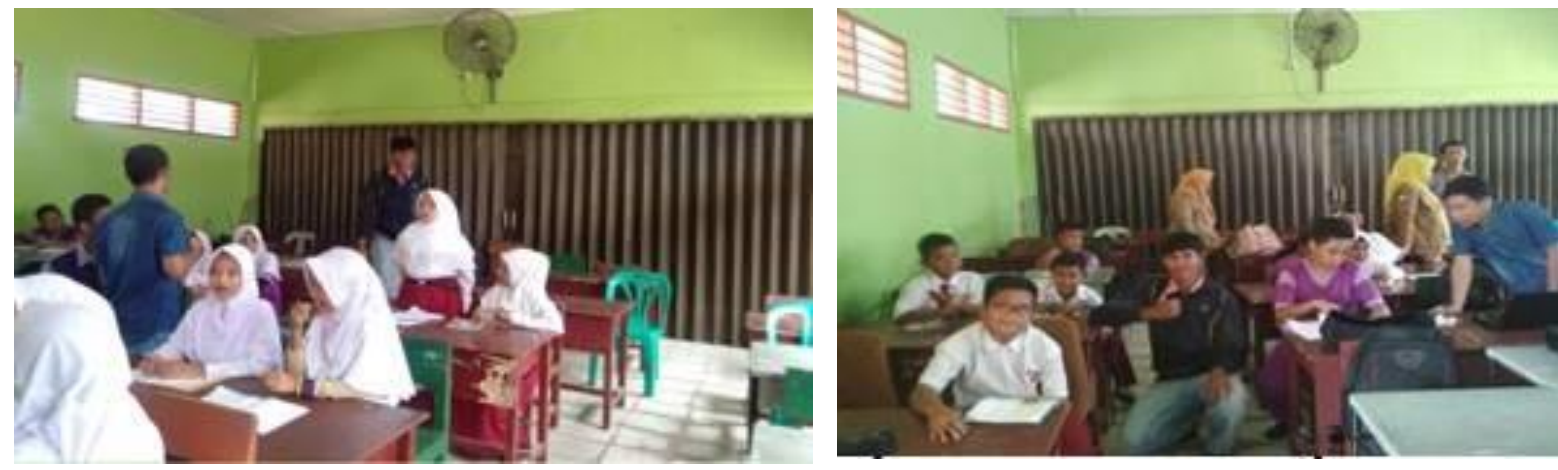

Gambar 3. Suasana di SDN 011 Tanjung pinang timur

Metode etnografi yang diterapkan pada penelitian ini adalah peneliti sebagai peserta, dimana kelompok yang sedang diteliti mengetahui tentang keberadaan peneliti, namun peneliti tidak ikut serta melakukan kegiatan dan aktifitas didalam kelompok yang sedang diteliti [10]. Pada Gambar 4 memperlihatkan peneliti melakukan proses pengumpulan informasi di SDN 011 Tanjung pinang timur.
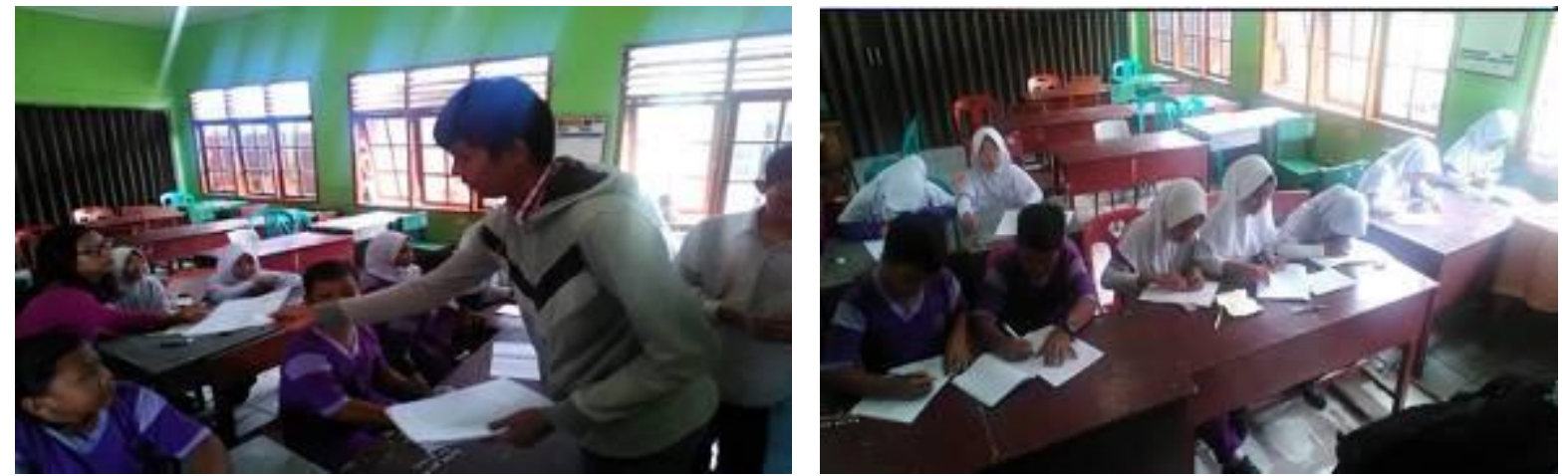

Gambar 4. Mengumpulkan informasi mengenai permasalahan yang terdapat di sekolah melalui siswa

\section{HASIL}

Jika ada yang siswa yang mengantuk guru membuka hp untuk menghidupkan suara ASET di meja tersebut dengan klik on/off.Tombol untuk mengidupkan ASET yang berwarna Hijau sedangkan untuk mematikan Aset berwarna merah.ASET ini berfungsi untuk membangunkan anak yang mengantuk atau tertidur. Sila lihat Gambar 5.

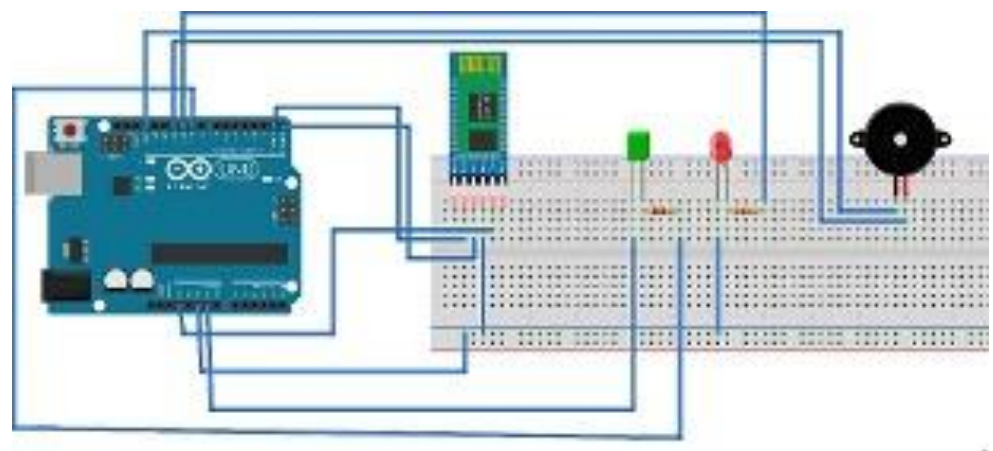

Gambar 5. Rangkaian elektronika sistem meja anti ngantuk menggunakan ArduinoUno dan Bluetooth

Adapun komponen yang diperlukan untuk pembuatan purwarupa dengan estimasi harga adalah sila lihat pada Tabel 1. 
Tabel 1. Estimasi anggaran ( Bukalapak, diakses 28 Mei 2019)

\begin{tabular}{llcrc}
\hline No. & Barang & Jumlah & $\begin{array}{c}\text { Harga per } \\
\text { satuan (Rp) }\end{array}$ & Total (Rp) \\
\hline 1 & Arduino & 1 & 80000 & 80000 \\
\hline 2 & Bluetooth HC 04 & 1 & 59500 & 59500 \\
\hline 3 & Breadboard & 1 & 32000 & 32000 \\
\hline 4 & Buzzer & 1 & 5000 & 5000 \\
\hline 5 & Kabel Jumper & 10 & 1000 & 10000 \\
\hline & Jumlah & & & 186500 \\
\hline
\end{tabular}

Purwarupa yang akan dihasilkan untuk meja anti ngantuk memerlukan komponen-komponen elektronika sebagai berikut :

Arduino Uno R3 adalah merupakan sebuah mikrokontroller, dimana mikrokontroler tersebut akan memproses input yang diberikan melalui bahasa pemograman open source sehingga akan menghasilkan output. Cukup hubungkan Arduino dengan kabel USB ke PC atau Mac/Linux anda, jalankan software Arduino sudah bisa untuk memprogram chip ATmega328. Sila lihat Gambar 6.

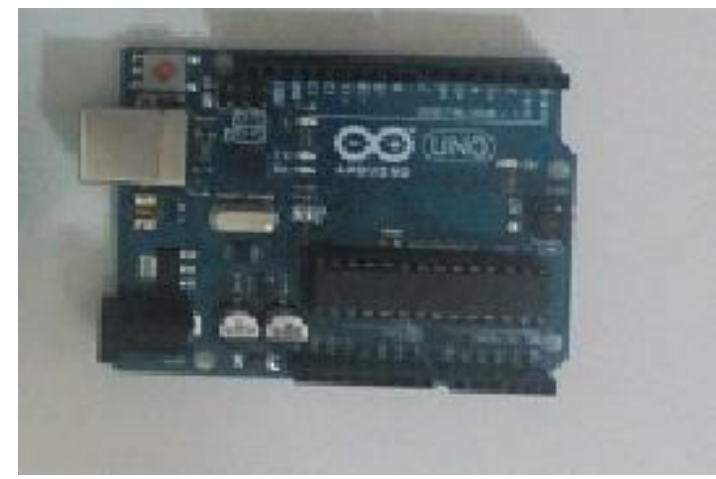

Gambar 6. Arduino Uno

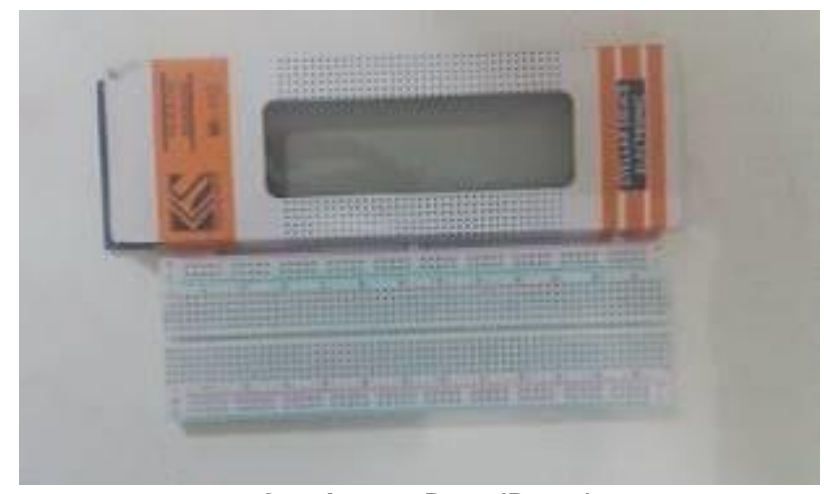

Gambar 7. BreadBoard

Breadboard adalah dasar konstruksi sebuah sirkuit elektronik dan merupakan purwarupa dari suatu rangkaian elektronik. Breadboard banyak digunakan untuk merangkai komponen, karena dengan menggunakan breadboard, pembuatan purwarupa tidak memerlukan proses menyolder (langsung tancap ). Karena sifatnya yang solderless alias tidak memerlukan solder sehingga dapat digunakan kembali dan dengan demikian sangat cocok digunakan pada tahapan proses pembuatan purwarupa serta membantu dalam berkreasi dalam desain sirkuit elektronika., sila lihat Gambar 7

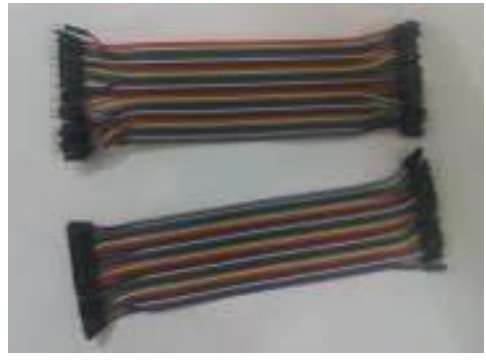

Gambar 8. Kabel Jumper

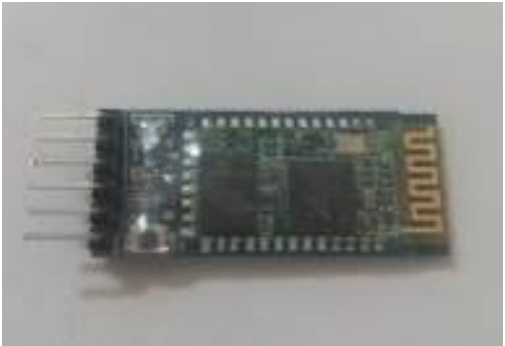

Gambar 9. Blueetooth

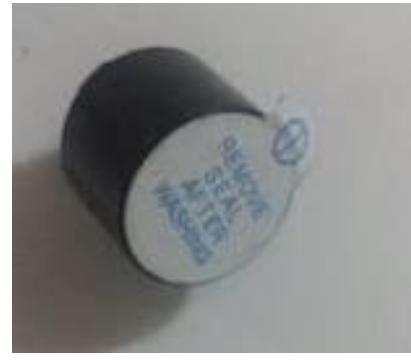

Gambar 10. Buzzer

Kabel jumper adalah kabel yang di pergunakan untuk menghubungkan satu komponen dengan komponen lain ataupun menghubungkan jalur rangkaian yang terputus pada breadboard, sila lihat Gambar 8. Bluetooth adalah sebuah alat yang dipergunakan untuk menghubungkan sebuah perangkat 
dengan perangkat lainnya tanpa kabel. Sila lihat Gambar 9. Buzzer adalah sebuah komponen yang akan menghasilkan suara melalui perubahan getaran listrik menjadi suara. Sila lihat Gambar 10.

\section{PEMBAHASAN}

Tahapan selanjutnya adalah curahan gagasan permasalahan yang ditemukan di sekolah dari hasil observasi, dimana semua permasalahan yang ditemukan akan di dokumentasikan. Proses ini adalah merupakan tahapan yang penting, karena sangat diharapkan bahwa solusi yang akan dihasilkan adalah merupakan solusi yang dibutuhkan, bukan solusi yang diminta oleh calon pengguna. Pola penyampaian gagasan secara bebas akan sangat diperlukan untuk memotivasi peneliti untuk mampu berpikir inovatif dan kreatif. Curahan gagasan yang bersifat luas adalah merupakan pondasi bagi rekayasawan untuk mampu menghasilkan sebuah inovasi yang berbasiskan teknologi. Hal ini sering dipahami dengan T concept, dimaksudkan bahwa inovasi yang dihasilkan memiliki pengaruh yang luas dan mendalam. Pada Gambar $\mathbf{1 1}$ dapat dilihat proses pengumpulan masalah-masalah yang sangat berkaitan dengan kejadian di sekolah selama melakukan observasi dan wawancara
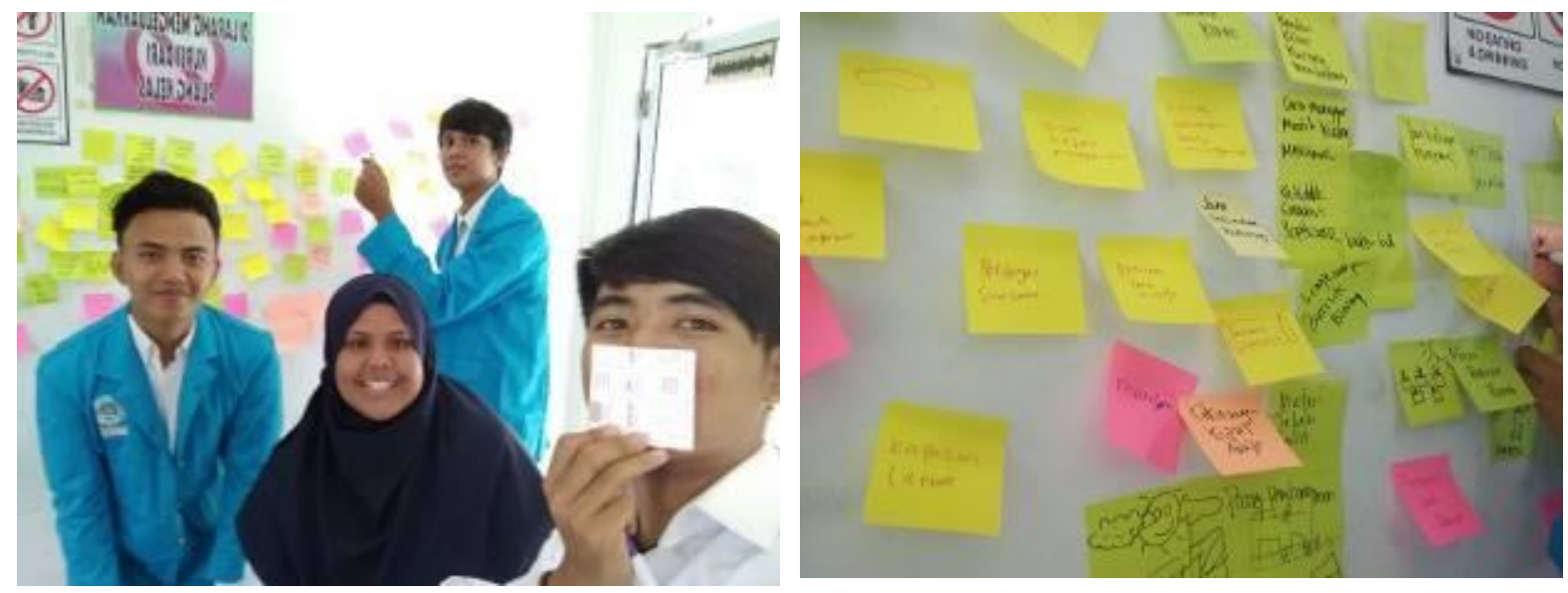

Gambar 11. Proses pengumpulan masalah

Permasalahan utama adalah satu permasalahan yang akan dijadikan landasan untuk langkah penentuan solusi, dalam tahapan ini akan dilakukan proses pengerucutan masalah, dimulai dengan pengelompokan masalah dan selanjutnya di pilih satu masalah saja, lihat Gambar 12. Proses diskusi bersama sesama anggota kelompok dengan saling memberikan penjelasan terhadap masalah yang akan dijadikan masalah utama diperlukan untuk mendapatkan informasi-informasi yang belum dapat disampaikan pada tahapan sebelumnya. Adapun permasalahan utama dari penelitian ini adalah mengantuk di kelas ketika sedang belajar.
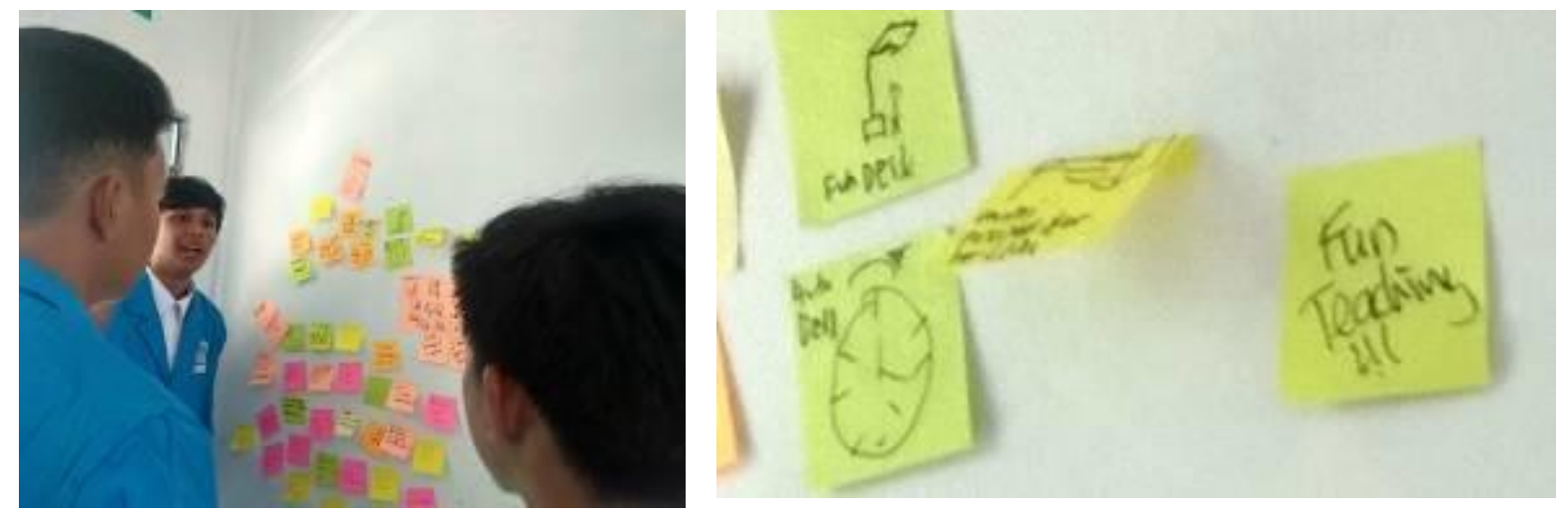

Gambar 12. Proses pengerucutan masalah untuk mendapatkan masalah utama

Tahapan curahan gagasan solusi dari masalah utama dilakukan setelah mendapatkan permasalahan utama. Dalam tahapan ini akan disampaikan beberapa konsep solusi bersama anggota 
peneliti lainnya. Dengan mempergunakan alat tulis yang dituangkan kedalam sketsa.Pada Gambar 13 menampilkan konsep solusi utama berupa perangkat meja anti ngantuk..

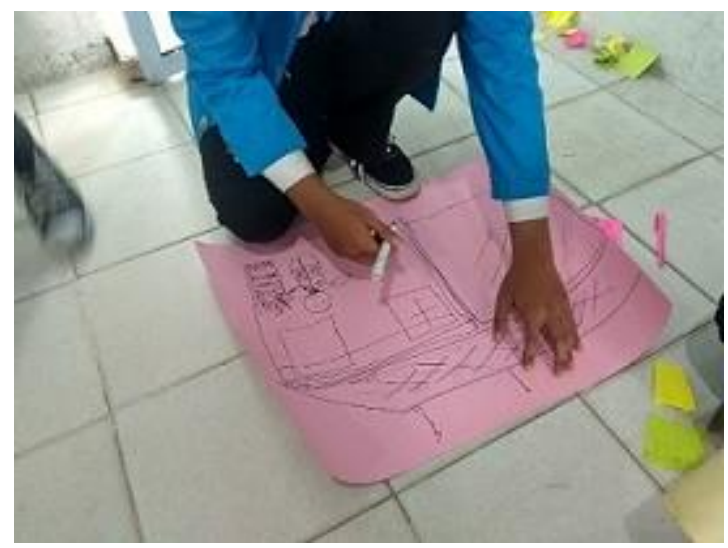

Gambar 13. Konsep solusi

\section{A. Purwarupa}

Tahapan yang sudah mulai memerlukan pembiayaan adalah tahapan pembuatan purwarupa. Oleh sebab itu pada Proses Desain Rekayasa ini, menekankan untuk mampu menghasilkan purwarupa sederhana yang ekonomis dan fleksible, dengan maksud bahwa perubahan rancangan dapat dilakukan dengan mudah dan tidak akan memerlukan pembiayaan yang besar. Purwarupa dalam tahapan ini lebih dikenal dengan istilah low resolution prototype [11]. Dapat dilihat pada Gambar 14 adalah sebuah purwarupa sederhana dari meja anti ngantuk...

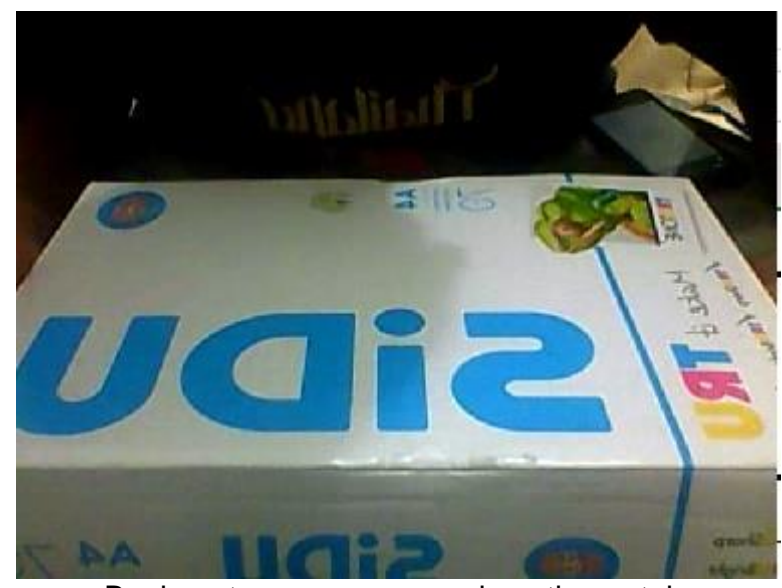

Bagian atas purwarupa meja anti ngantuk

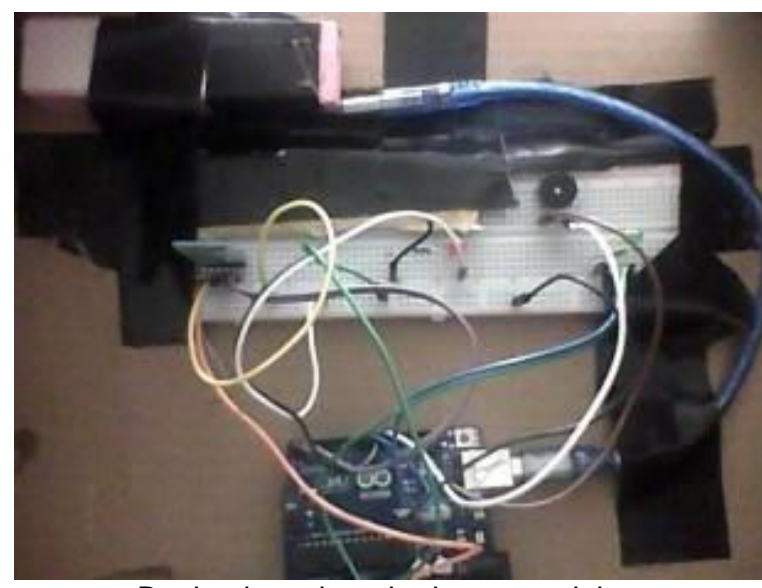

Bagian bawah meja dengan arduino

Gambar 14. Purwarupa Sederhana

\section{B. Pengujjian Kegunaan}

Pengujian kegunaan adalah proses evaluasi terhadap inovasi yang dirancang dengan berbasis pengguna. Pada tahapan ini pengguna akan berpartisipasi dan berinteraksi secara langsung dengan purwarupa sederhana yang dihasilkan dari proses sebelumnya. Pengguna akan diminta untuk melakukan tugas tertentu atau hanya menjelajahinya secara bebas, sementara perilaku pengguna diamati dan dicatat untuk mengidentifikasi kelemahan desain yang menyebabkan kesalahan atau kesulitan pengguna. Selama pengamatan ini, Setelah kelemahan desain telah diidentifikasi, rekomendasi desain diusulkan untuk meningkatkan kualitas ergonomis produk [12]. Sila lihat pada Gambar 15. 


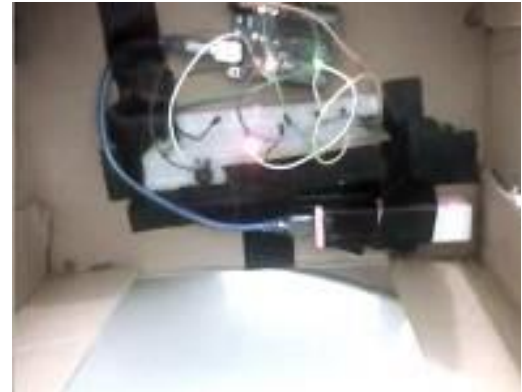

Purwarupa yang dipasang pad bagian bawah setiap meja siswa

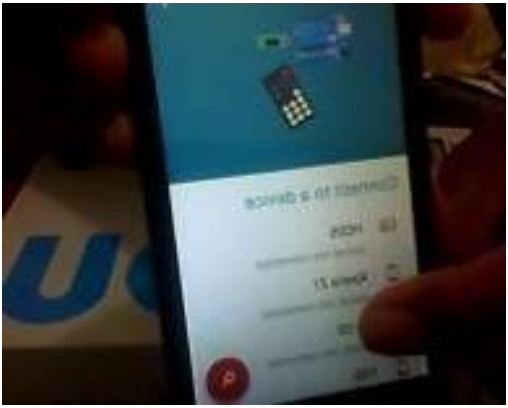

Mengaktifkan fungsi bluetooth

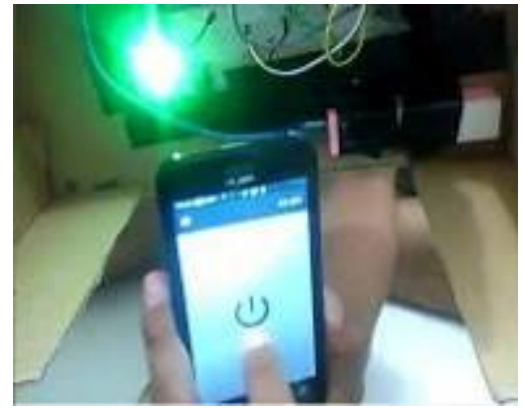

Menekan tombol untuk menguji fungsi pengendali jarak jauh

Gambar 15. Pengujian kegunaan

\section{Program pada Arduino}

Dibawah ini adalah program yang ditulis pada Arduino untuk dapat menghasilkan luaran sesuai yang di inginkan pada Meja Anti Ngantuk

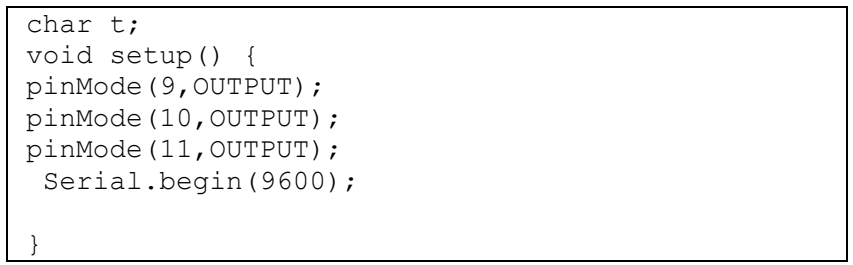

Gambar 16. Void setup menentukan input / output komponen yang digunakan.

Pada Gambar 16 menjelaskan bahwa di dalam void setup terdapat 3 output, yang pertama pada pin 9 arduino ke pin TX Bluetooth module, pin 10 arduino ke pin RX Bluetooth module, dan pin 11 arduino sebagai output dari buzzer.

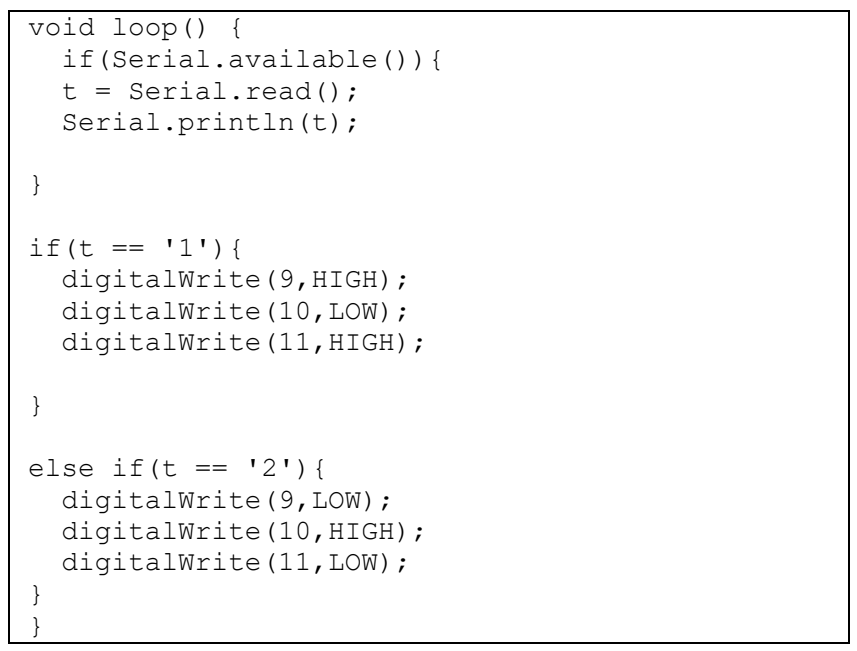

Gambar 17. Mengatur fungsi perulangan pada void loop.

Sedangkan pada Gambar 17 menejelaskan bahwa purwarupa ini menggunakan komponen Bluetooth module yang terkoneksi dengan aplikasi Bluetooth smartphone, yang pada saat kita tekan tombol ON pada aplikasi Bluetooth di smartphone maka buzzer akan menyala sehingga status pada pin 11 arduino $\mathrm{HIGH}$. 


\section{DAMPAK DAN MANFAAT}

Pengalaman pengguna akan memperluas pandangan tentang interaksi produk dengan pengguna dari aspek emosional. Adapun motivasi dari proses pengalaman pengguna adalah untuk mengembangkan pengalaman dan emosi positif. Oleh karena itu, produk harus memenuhi kebutuhan psikologis dan motif pelanggan [13]. Pada Gambar 18 menampilkan pengujian pengalaman pengguna kepada siswa.

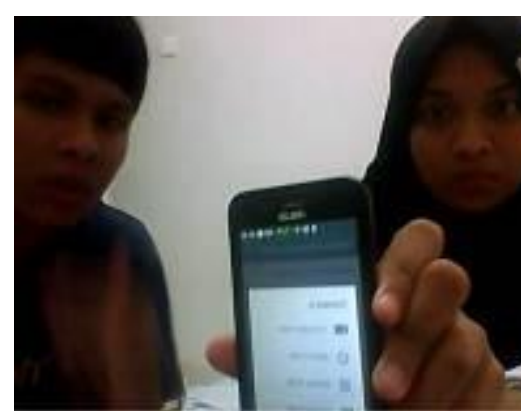

Tahapan awal pengujian menggunakan Bluetooth pada telpon pintar

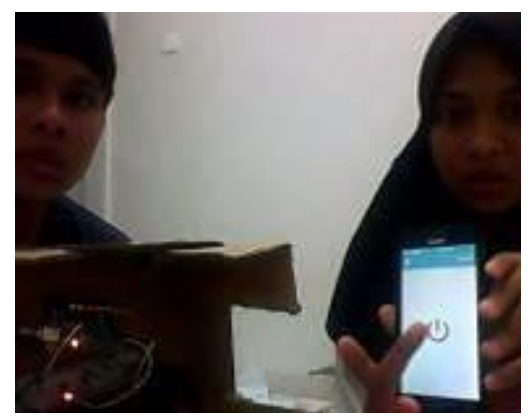

Tombol untuk mengaktifkan buzzer pada telpon pintar

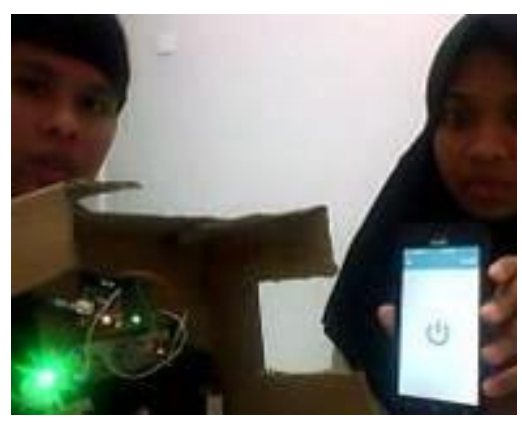

Tombol ditekan, maka buzzer pad meja siswa akan berbunyi dan lampu hijau menyala

Gambar 18. Pengujian pengalaman pengguna kepada siswa

Pada Gambar 19 menampilkan pengujian pengalaman pengguna kepada masyarakat.

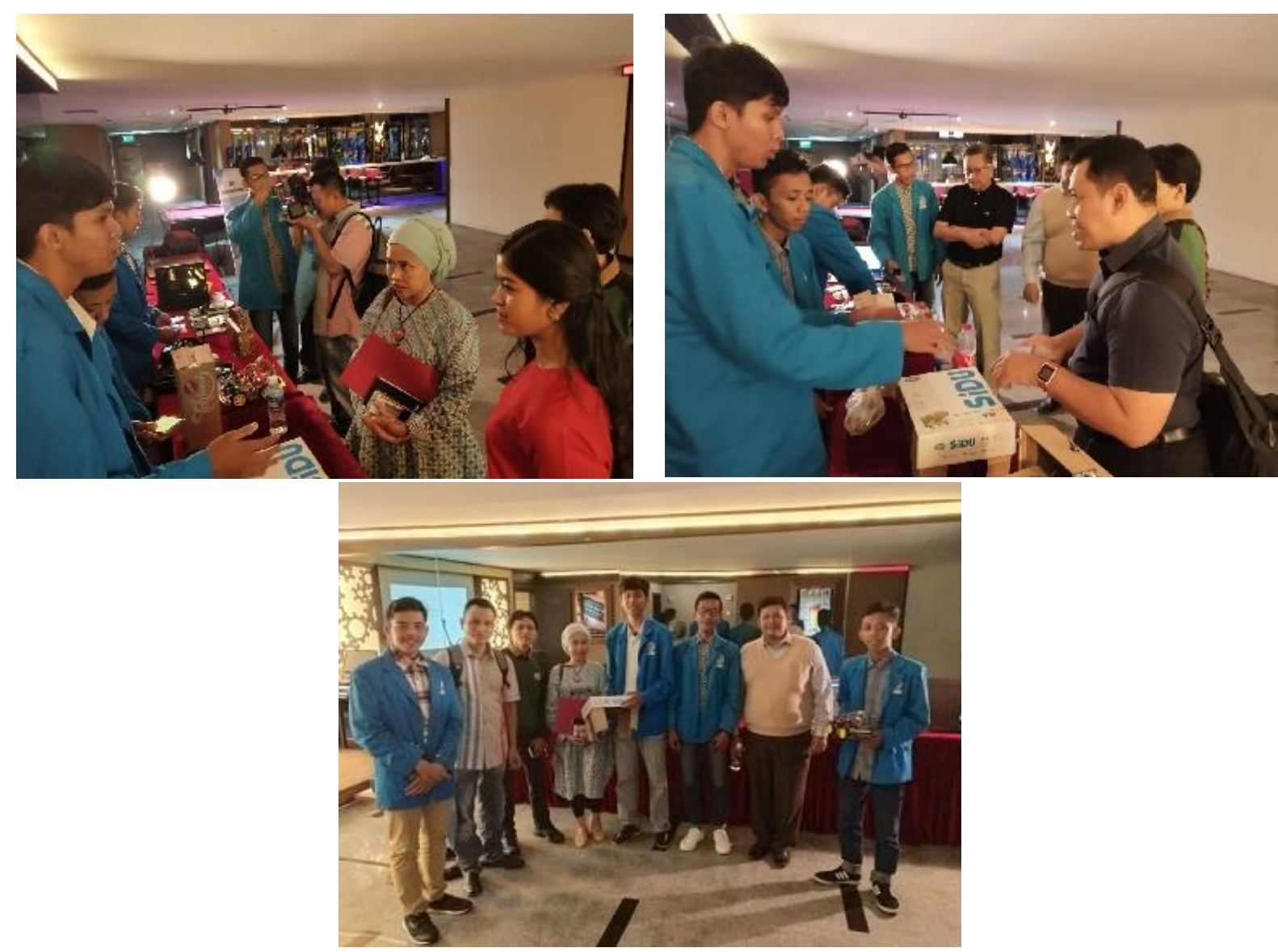

Gambar 19. Pengujian pengalaman pengguna kepada masyarakat

Inovator yang berbasiskan teknologi sangat sadar bahwa kesuksesan hasil inovasi tidak hanya dilihat dari manfaat dari produk yang akan dihasilkan namun juga perlu memperhatikan faktor 
pengalaman pengguna., sehingga pengembangan inovasi teknologi tidak lagi hanya tentang mengimplementasikan fitur dan menguji kegunaannya, tetapi juga tentang mendesain produk yang menyenangkan dan mendukung kebutuhan dan nilai-nilai dasar manusia. Dengan demikian, pengalaman pengguna dalam tahapan Proses Desain Rekayasa harus menjadi perhatian utama pengembangan produk [14],

Dari hasil pengujian pengalaman pengguna dapat dilihat jika purwarupa yang dihasilkan mudah untuk digunakan dan menarik, selain itu dengan sistem yang ada saat ini sudah dapat diaplikasikan karena sesuai dengan keperluan pengguna. Inovasi yang dihasilkan masih dalam tahapan awal perancangan sehingga masih diperlukan optimalisasi fungsi. Sila lihat Tabel 2 dan Tabel 3

Tabel 2. Hasil pengujian dari calon pengguna pertama

Tabel 3. Hasil pengujian dari calon pengguna

\begin{tabular}{|c|c|c|c|c|c|c|}
\hline & 4 & 3 & 2 & 1 & \multirow[b]{2}{*}{ Keterangaan } \\
\hline & & $\begin{array}{l}\text { Sangat } \\
\text { Baik }\end{array}$ & Baik & Cukus & Kurang & \\
\hline 1 & \begin{tabular}{|l|} 
Puwwarupa ini \\
mudah \\
digunakan?
\end{tabular} & & & & & mudah dipergunakan \\
\hline 2 & \begin{tabular}{|l} 
Apakah inovasi \\
ini menarik?
\end{tabular} & & & & & \begin{tabular}{|l} 
menarik untuk \\
diaplikasikan
\end{tabular} \\
\hline 3 & $\begin{array}{l}\text { Apakah inovasi } \\
\text { ini berguna di } \\
\text { lingkungan } \\
\text { masyarakat? }\end{array}$ & & & & & $\begin{array}{l}\text { dapat dipergunakan di } \\
\text { sekolah yang ada kelas } \\
\text { siang }\end{array}$ \\
\hline 4 & $\begin{array}{l}\text { Apakah fungsi } \\
\text { dari inovasi ini } \\
\text { baik? }\end{array}$ & & & & & sangat baik \\
\hline 5 & $\begin{array}{l}\text { Apakah sistem } \\
\text { dalam inovasi ini } \\
\text { sudah optimal ? }\end{array}$ & & & & & $\begin{array}{l}\text { perlu menambah fungsi } \\
\text { getar }\end{array}$ \\
\hline
\end{tabular}

\begin{tabular}{|c|c|c|c|c|c|c|}
\hline \multicolumn{7}{|c|}{ kedua } \\
\hline & & \begin{tabular}{|l|l|}
4 \\
\end{tabular} & 3 & & 1 & \\
\hline & & $\begin{array}{c}\begin{array}{c}\text { Sangat } \\
\text { Baik }\end{array} \\
\end{array}$ & Baik & Cukut & Kurang & Keterangaan \\
\hline 1 & $\begin{array}{l}\text { Prototipe ini } \\
\text { mudah } \\
\text { digunakan? }\end{array}$ & & & & & $\begin{array}{l}\text { sangat mudah } \\
\text { dipergunakan }\end{array}$ \\
\hline 2 & $\begin{array}{l}\text { Apakah inovasi } \\
\text { ini menarik? }\end{array}$ & & & & & $\begin{array}{l}\text { sangat menarik karena } \\
\text { belum pernah dibuat }\end{array}$ \\
\hline 3 & \begin{tabular}{|l} 
Apakah inovasi \\
ini berguna di \\
lingkungan \\
masyarakat?
\end{tabular} & & & & & $\begin{array}{l}\text { dapat dipergunakan oleh } \\
\text { sekolah }\end{array}$ \\
\hline 4 & \begin{tabular}{|l} 
Apakah fungsi \\
dari inovasi ini \\
baik?
\end{tabular} & & & & & $\begin{array}{l}\text { puwwarupa dapat berfungsi } \\
\text { dengan baik dan sederhana }\end{array}$ \\
\hline 5 & $\begin{array}{l}\text { Apakah sistem } \\
\text { dalam inovasi ini } \\
\text { sudah optimal ? }\end{array}$ & & & & & $\begin{array}{l}\text { perlu menambahkan fungsi } \\
\text { suara lainnya }\end{array}$ \\
\hline
\end{tabular}

\section{SIMPULAN DAN SARAN}

Aktivitas belajar siswa di sekolah ada umumnya dimulai pada pagi hari, pada saat menjelang siang hari siswa sering mendapatkan rasa kantuk. Hal ini dapat ditimbulkan karenaa siswa yang kelelahan setelah melakukan aktivitas fisik sebelumnya, ataupun faktor cuaca di sekitarnya. Inovasi berbasiskan teknologi dengan nama Meja Anti Ngantuk adalah merupakan sebuah solusi yang dapat menghindari siswa dari kantuk. Dengan menggunakan buzzer yang dipasang pada meja siswa, guru akan dapat menyadarkan siswa dengan menekan tombol tertentu pada telpon pintar secara jarak jauh. Dari hasil pengujian pengalaman pengguna (user experience) telah didapatkan hasil yang memuaskan. Adapun saran yang didapatkan dari hasil pengujian adalah perlunya inovasi meja anti ngantuk untuk kembangkan selanjunya dengan fungsi tambahan, selain itu didalam pengujian dapat melibatkan siswa di beberapa sekolah secara langsung. Untuk merealisasikan saran tesebut, maka diperlukan kerjasama antara perguruan tinggi dan pemerintah daerah setempat.

\section{UCAPAN TERIMAKASIH}

Terima kasih kepada civitas akademika di jurusan teknik elektro Universitas Maritim Raja Ali Haji (UMRAH) dan redaksi Jurnal JPTK Universitas Pendidikan Ganesha yang telah memberikan kesempatan untuk publikasi.

\section{DAFTAR PUSTAKA}

[1] Poli E P, Lumenta A S M, Sugiarso B A, and Wuwung J O, Deteksi Rasa Kantuk Pada Pengendara Kendaraan Bermotor Berbasis Pengolahan Citra Digital, Jurnal Teknik Elektro dan Komputer, Universitas Sam Ratulangi, 2013, 2(2) : 1-6

[2] Pradana I S, Pendeteksi Kantuk Menggunakan Metode Plethysmograph, Projek ahir D4, Politeknik Negeri Bandung, 2017

[3] Permana I, Harasani P, and Negara T P, Alat Pendeteksi Rasa Kantuk Melalui Pulse Sensor Berbasis Arduino Uno, Tugas ahir S1, Universitas Pakuan, 2017 
[4] Arthana I K R, Pradnyana I M A, and Kurniati D P Y, Sistem Monitoring Detak Jantung dan Lokasi Pasien, Jurnal Pendidikan Teknologi dan Kejuruan, Universitas Pendidikan Ganesha, 2018, 15(1) :124-133

[5] Kastner S, and Knight R T, Bringing Kids into the Scientific Review Process. Journal Neuron, Elsevier Inc, 2017, 93(1) : 12-14.

[6] Irbīte A, and Strode A, Design thinking models in design research and education, Proceedings of the International Scientific Conference, 2016, IV : 488-500

[7] How Design Thinking Works [Daring], Tersedia pada : http://www.andyeklund.com/how-designthinking-works/ [ Diakses : 31 Mei 2019 ].

[8] Stanford University [Daring], Tersedia pada : http://web.stanford.edu [ Diakses : 31 Mei 2019 ].

[9] Sekolah Kita [Daring], Tersedia pada: http://sekolah.data.kemdikbud.go.id/index.php/chome/profil/008518BD-31F5-E011-A76D4BED2BF3B038 [ Diakses : 31 Mei 2019 ]..

[10] Wagner C, Kawulich B, and Garner M, Collecting Data Through Observation, Doing Social Research: A global context, McGraw Hill, 2012

[11] Nusyirwan D, Engineering Design Process Engineering Student Centered Experience Learning (ESCEL) di Jurusan Teknik Elektro Universitas Maritim Raja Ali Haji (UMRAH). Jurnal Sustainable, Universitas Maritim Raja Ali Haji, 2017, 6(1) : 24-35

[12] Bastien J M C, Usability testing: a review of some methodological and technical aspects of the method", International Journal of Medical Informatics, Elsevier Ireland Ltd, 2010, 79(4) : e18-e23.

[13] von Saucken C, Lachner F, and Lindemann U, Principles for User Experience What We Can Learn from Bad Examples, International Conference on Kansei Engineering \& Emotion Research, 2014

[14] G. I. Johnson, \& C. W. Clegg, \& S. J. Ravden, Towards Practical User Experience Evaluation Methods, Jornal of Applied Ergonomics, Elsevier Ltd, 1989, 20(4) : 255-260 